\title{
Challenges of Planning Secondary School Education in Federal Capital Territory of Abuja, Nigeria
}

Desafíos de la planificación de la educación secundaria en Abuja, territorio de la capital federal de Nigeria

\begin{abstract}
The study investigated the challenges facing the planning of secondary schools education in the Federal Capital Territory (FCT) of Abuja, Nigeria. The research design for the study was a survey method. The target population is comprised of educational planners working in the ministry, department and agency of education that deals with education planning. The sample for this study was eighty people by random sampling technique using four agencies of the federal government in FCT, Abuja. A structured questionnaire was used for data collection in the study. The reliability of the instrument was determined by testing and retesting. The data were analyzed using frequency counting and simple percentage. The result of the study showed; inadequate planning information, inadequate planning materials, poor educational planner training, political instability. Inadequate funding for planning activities and a shortage of professional educational planners are the challenges facing planning for secondary schools in FCT, Abuja, Nigeria.

Keyword: Planning; High School; Challenges; Nigeria

\section{RESUMEN}

El estudio investigó los desafíos que enfrenta la planificación de la educación secundaria en el Territorio de la Capital Federal (FCT) de Abuja, Nigeria. El diseño de la investigación para el estudio fue un método de encuesta. La población objetivo compuesta por planificadores educativos que trabajan en el ministerio, departamento y agencia de educación que se ocupa de la planificación educativa. La muestra para este estudio fue de ochenta personas, mediante una técnica de muestreo aleatorio utilizando cuatro agencias del gobierno federal en FCT, Abuja. Se utilizó un cuestionario estructurado para la recopilación de datos en el estudio. La fiabilidad del instrumento se determinó mediante la prueba y la nueva prueba. Los datos se analizaron utilizando el conteo de frecuencias y el porcentaje simple. El resultado del estudio mostró; información inadecuada para la planificación, materiales de planificación inadecuados, capacitación deficiente del planificador educativo, inestabilidad política. El financiamiento inadecuado para las actividades de planificación y la escasez de planificadores educativos profesionales son los desafíos que enfrenta la planificación de las escuelas secundarias en FCT, Abuja, Nigeria.
\end{abstract}

Palabras clave: Planificación; Escuela secundaria; Desafíos; Nigeria 


\section{INTRODUCTION}

Secondary Education in Nigeria is education meant for children from basic education that prepares the learners for higher education, which is based on the 6-3-3-4 educational system. Secondary education will last for six years. Secondary school education is in two forms. The first stage is the junior secondary school stage, and the second stage is the stage for the senior secondary school. All the stages run for three years as planned in the National Policy on Education. The objectives of the Secondary schools in Nigeria is divided into two, the broad aim of secondary education within the overall national objectives is to prepare the students for higher education and for living a responsible life in society while the subobjective are to: provide all primary school leavers with the opportunity for education of a higher level, irrespective of sex, social status, religion or ethnic background; Offer diversified curriculum to cater for the differences in talents, opportunities and future roles; Provide trained manpower in the applied science, technology and commerce at sub-professional grades; Develop and promote Nigerian languages, art and culture in the context of world cultural heritage; Inspire its students with a desire for self-improvement and achievement of excellence; Foster national unity with an emphasis on the common ties that unite us in our diversity; Raise a generation of people who can think for themselves, respect the view and feelings of others, respect the dignity of labor, appreciate those values specified under our broad national goals and live as good citizens and Provide technical knowledge and vocational skills necessary for agricultural, industrial, commercial and economic development.

Senior secondary education has a diversified curriculum, with subjects designed to broaden students' knowledge and outlook in life. The language of instruction is English for all secondary school grades, except for special courses that require another language. Every student takes six core subjects, plus a minimum of two and a maximum of three from the list of elective subjects. In summary, they have to take a minimum of eight subjects but not more than nine. The core subjects are English; mathematics; one major Nigerian language; one elective out of biology, chemistry, physics, or integrated science; one elective out of English literature, history, geography or social studies; and agricultural science or a vocational subject. One of the three elective subjects may be dropped in the last year of the senior secondary course. The promotion of students from one class to another is determined by a combination of continuous assessment scores and end-of-term examinations. The Senior School Certificate examination is taken in the last year of senior secondary education, and a certificate is awarded on successful completion and passing of a national examination, which is conducted by West African Examinations Council or the National Examinations Council.

The planning, administration, and management of education in Nigeria has shared responsibilities between the Federal government of Nigeria, state government, and the local government councils. In Nigeria since 1999 where the Constitution was drafted, Education has been placed on the concurrent legislative list. The implication of this concurrent legislative list means that both Federal and State Governments are constitutionally bound with functions and responsibilities in respect of education. The constitution gives the federal government more power and functions. However, most of the functions are shared by the three tiers of government. The funding of education in Nigeria is the responsibility of both the federal and state governments.

Specifically, the federal government is responsible for the planning of education in Nigeria in collaboration with the states and the local government councils. The Federal ministry of education carries out the following functions; formulating a national policy on education, collecting and collating data for purposes of educational planning and financing, maintaining uniform standards of education throughout the country, and controlling the quality of education in the country through the supervisory role of its Inspectorate Services Department. The Federal Ministry of Education also harmonizes educational policies and procedures of all the states of the federation through the instrumentality of the National Council on Education. It also affects cooperation in educational matters on an international scale. The Federal Ministry Education coordinates the activities of a number of parastatals under it such as the National Universities Commission (NUC), the National Commission for Colleges of Education (NCCE), the National Board for Technical Education (NBTE) and the Universal Basic Education Commission (UBEC).

The state government manages education in the state through the Ministry of Education, the Post Primary Education Board and the State Primary Education Board. The Ministry is responsible for the formulation of educational policies for the state. The policy is expected to derive from the National Policy on Education at the federal level. The departments in the ministry of education implement the state policy on education. There are specialized departments whose functions pertain to specific aspects of the education sector. They are: 
- Planning, Research and Statistics Department;

- Science, Vocational and Technical Department;

- Schools Department;

- The Inspectorate Department

- Higher Education;

- Examinations and Standards Noun, (2008 p. 62)

The State Governments also have educational parastatals. Major examples are Teaching Service Commissions, Science and Technical Education Boards, State Primary Education Boards (SPEBs), State Mass Education Commission (SMECs), Governing Councils of tertiary institutions, and Scholarship Boards.

To achieve the objectives of the educational system in Nigeria, there is a need to properly plan the entire educational system. The achievement of the objectives of national policy on education hinges on the quality of its planning. Planning is very important in the educational sector. Planning is needed in basic education, secondary school education, and higher education.

The place of planning in the educational system cannot be underestimated because it is only through effective planning that the broad goals of national education can be realized. Planning is needed in all the segments of the educational sector. The importance of planning education includes:

- To reduces wastages in the educational system;

- To ensure effective distribution of school facilities;

- To ensure effective and efficient allocation of limited educational resources

- To attain quality in the system

To achieve an adequate supply of manpower, instructional and infrastructural facilities.

Effective planning of education will also help to ensure adequate funding which is very important to educational development.

Factors to consider while planning education, the population of students, the manpower, the infrastructural facilities, the funding, the location, and the objective of the education program. Another thing to consider include the curriculum and the school plant

The educational system must develop a plan that ensures that the appropriate products and services are offered to its students. More specifically, planning gives guidance and direction to members of an organization as to their role in delivering the products and services (Peretomode 1991, 1995; Naylor, 1999).

Education is the tool for achieving national development in the time of technology, political, economic, and social development. Because of this great contribution to education, effective planning of education is inevitable for balanced development in the entire country.

Akpan (2000) observed that the success of any educational system depends greatly on effective panning. Planning is the process of examining the future and drawing up appropriate actions for achieving specified goals and objectives. Educational planning on the other hand involves the setting of educational goals and objectives, the formulation of educational policies, and the coordination of educational programs and activities that would lead to the accomplishment of the predetermined educational goals and objectives. It also involves financial planning and budgeting as well as human resource planning.

As important as planning for educational development is, it is unfortunate that the planning of education in Nigeria is not given more priority. Moja (2000, p. 39) submitted that planning, supervision, and monitoring mechanisms for the entire education system have been very weak. The poor planning of education is reflecting on all the forms of the educational system in the country. Basic education is beset with issues like shortage of professional teachers, inadequate infrastructural facilities, underfunding, high student-teacher ratio, a high number of school children, and poor quality of learning.

The Nigerian secondary school education due to poor planning is also plagued with many challenges. These challenges include a lack of instructional materials, inadequate infrastructural facilities, shortage of professional teachers, and overcrowding of classes. Moja (2000 p.19) observed that inadequate planning and funding as well as the inadequacies of the monitoring processes for the implementation of 
national policy on education contributed to a lack of classroom space in the sub-sector.

According to Alabi (2016, p. 66), the Nigerian Secondary School education system is characterizing with many issues and problems. These problems range from inadequate funding, inadequate teachers, the poor motivation of teachers, inadequate instructional materials, inadequate infrastructural facilities, and poor quality of teaching and learning.

In the Federal Capital Territory, Abuja, the situation of Secondary school education is not different from other parts of the Country. According to Abdull (2016, p. 45), Senior Secondary Schools in Abuja FCT are plagued with challenges which include a shortage of professional teachers, especially science teachers, inadequate funding, inadequate infrastructural facilities, lack of effective supervision, and large classes.

Based on the poor planning of Secondary school education in Nigeria and in FCT, Abuja, Nigeria. It is very important that the researcher should look at the challenges facing the planning of Secondary School education in Nigeria.

\section{LITERATURE REVIEW}

\subsection{Educational Planning}

There are many definitions of planning. Planning involves the act of setting goals, identifying means or strategies, and systematically outlining tasks and schedules to accomplish the goals. Planning and management have something in common, planning is the basic function of management, and it is a process of setting goals, developing strategies, and outlining tasks and schedules to accomplish the goals. It also refers to the process of deciding what to do and how to do it. Planning occurs at many levels, from day-to-day decisions made by individuals and families, to complex decisions made by businesses and governments.

Educational planning can be defined as the process of outlining the educational objectives and identifying the strategies to achieve the defined objectives. Educational planning involves systematic planning of the entire educational sector with the objectives of achieving its various set goals. Adepoju (2000) sees educational planning as the process of identifying educational needs and the direction education should take and how to implement decisions. This means that educational planning must reflect the state of development of a nation, including its needs and the readiness to execute the planned objectives.

Adesina (1981) pointed out that educational planning is the process of applying scientific or rational procedures to the process of educational growth and development so as to ensure the efficiency and effectiveness of the educational system through a planning mechanism while Akpan (2000) pointed out that educational planning must take into account the population growth of children of school age in relation to educational opportunities and the demand for education. Educational planning should take into account political, economic, and social changes going on in society as well as technological changes.

There are a few empirical studies and articles on educational planning in Nigeria. Some of the accessible ones include that of Nwachukwu (2013 p. 1) who observed that the Nigerian educational system has undoubtedly encountered a number of significant impediments in the last few decades, and it continue to struggle with the implementation and assurance of educational and teaching quality because of lack of effective planning. A shortage of accurate statistical data, financial, qualified planners, poor national economic performance, unsuitable governing structures, political interference, and general instability have all contributed to low quality in educational planning. This paper looks at the meaning and context of educational planning and the planning process. The paper concludes that in spite of the increasing complexity of schools created by rising enrollments and problems of research, programs of study must be tailored to the ever-more complex needs of the society. Schools are established for the improvement of society, and thus, socio-economic planners and educational planners need to cooperate in planning for the benefit of both the school and society.

Education planning today, according to Ogundele (2004 p. 23) is faced with numerous challenges that required more sophisticated and better planning approaches to succeed. Some of these challenges bordered on curriculum structure, decision implementation, leadership, and environmental constraint, implementation of academic programs are carried out without in-depth analysis of problems and challenges they are expected to address. Education plans and decision implementation channels are taken in a haphazard manner without proper initiatives. In other words, there is so much of whims and caprices approach to education program planning and implementation in schools, particularly unity schools due 
perhaps to response of the government to political pressure and sometimes because of the desire to score cheap political points and as a means of fueling corruption in the system.

Longe (2013 p. 1) observed that some of the thorny problems identified are: crude data/unreliable information produced at that level (which have made educational planning difficult), political influence, funding, cultural and social rigidities, low level of income among others. The paper suggests raising funds to implement educational programs, proper orientation to break the barriers posed by cultural and social rigidities, paying more attention to local communities, and calling on all and sundry to revive education at this level, all these being the way out for well-articulated educational planning.

Inadequate data/information for planning, political instability, political influence, poor planning method, inadequate funding of planning, shortage of planning materials, lack of capacity development for educational planners, and insecurity.

\subsection{Secondary School Education}

Secondary schools are defined as the post-primary school education. Secondary school education is the bridge between primary and higher education. It is the ladder to clap to higher education. Secondary Education is the education that children receive after primary education and before the tertiary education. Based on the 6-3-3-4 system of education, secondary education comprises six years duration, but given in two stages: a junior secondary school stage and a senior secondary school stage, each to run for three years duration.

Junior Secondary School: The junior secondary school is both pre-vocational and academic. It is tuition free, universal and compulsory. Basic subjects that will enable students to acquire further knowledge and skills are taught. Students who complete junior secondary school are to be streamed into:

a. The senior secondary school

b. The technical college

c. An out-of-school vocational training center

d. An apprenticeship.

Senior Secondary School: This is the second phase of secondary education. It is comprehensive with a core-curriculum designed to broaden students' knowledge. This is the stage where students pick subjects of their choice and begin to prepare for their intended careers.

The broad goals of Secondary Education according to the National Policy on Education (2004) include, the preparation of the individual for:

i. Useful living within the society and

ii. Higher education.

In specific terms, the objectives are to:

a. Provides all primary school leavers with the opportunity for education of a higher level, irrespective of sex, social status, religion or ethnic background;

b. Offer diversified curriculum to cater for the differences in talents, opportunities and future roles;

c. Provide trained manpower in the applied science, technology and commerce at sub-professional grades;

d. Develop and promote Nigerian languages, art and culture in the context of world cultural heritage;

e. Inspire its students with a desire for self-improvement and achievement of excellence;

f. Foster national unity with an emphasis on the common ties that unite us in our diversity;

g. Raise a generation of people who can think for themselves, respect the view and feelings of others, respect the dignity of labor, appreciate those values specified under our broad national goals and live as good citizens;

h. Provide technical knowledge and vocational skills necessary for agricultural, industrial, commercial and economic development. 
There are many studies on different aspects of Nigerian secondary schools' education. Mohammed \& Bint (2012) discussed the challenges Nigerian teachers are facing in public secondary schools [Government-owned schools] and its effects on the present rising student's dropouts. A secondary school in Nigeria is an educational stage to be attended by students after primary school and before tertiary institutions. This is a period for youth direction on subject specialization, leading to issues of professionalization base on subject compartmentalization and choice of higher institution. The significance attached to this requires a productive school climate with efficient resources for teaching and learning. Nigeria's public secondary school climate is facing the challenges of inadequate professional capability, poor school preparatory ground, and the absence of facilities to cater to students. In terms of curriculum contents, there is a total mismatch between stated policy on education and the provision of teaching facilities and structural preparation.

These overstretched public secondary school problems which cannot be managed by authority and be accepted by education clients had led to frequent absenteeism, poor performance, and constant student dropout. This easily predicts the future of unproductive youths, and these classes of citizens will be unskilled and unproductive. Thus, teachers are strongly finding it difficult to meet up to the expectations of the teaching profession, because the school climate is not conducive for both teaching [teacher] and learning [student].

Nnebedum, \& Akinfolarin, (2017) looked at the persistent and prolonged pitiable state of teachers' job performance leading to poor academic achievement of secondary school students in Ebonyi State. It has become a source of concern and worries among stakeholders and parents. This could be that instructional supervision is not regularly performed by the principals in order to provide professional guidance and assistance to teachers to enable them to improve on their instructional delivery. It, therefore, becomes necessary to investigate the relationship between principals' supervisory techniques and teachers' job performance in secondary schools in Ebonyi State. The study was guided by three research questions and three hypotheses were tested at 0.05 level of significance. The study adopted a correlation research design. The study population comprised 4,368 secondary school teachers in Ebonyi State. A stratified proportionate sampling technique was used to sample 1005 respondents from the population of the study.

The researchers developed two sets of instruments titled "Principals' Supervisory Techniques Questionnaire (PSTQ)" and "Teachers' Job Performance Questionnaire (TJPQ)" were used for data collection. The instrument was subjected to face and content validation by three experts who are lecturers; two in the Department of Foundations and the other in the Measurement and Evaluation Unit in the Department of Science Education, all from Faculty of Education, Ebonyi State University, Abakaliki. Cronbach alpha was employed for the reliability test and this yielded a coefficient of $0.78,0.68$, and 0.81 for the three parts of PSTQ and 0.78 for TJPQ respectively. Pearson product-moment coefficient was used in answering the research questions and a t-test was used in testing the hypotheses. The findings of the study revealed among others that there is a high positive correlation between classroom observation techniques and teachers' job performance in secondary schools in Ebonyi State. It also revealed that there was a significant relationship between principals' demonstration techniques and teachers' job performance in secondary schools in Ebonyi State. Based on the findings, the conclusion was drawn and it was recommended among others that government should provide an opportunity for principals to attend conferences, workshops, seminars and colloquiums on supervisory techniques at least once a year both nationally and internationally for more acquisition of skills and knowledge for effective instructional supervision in order to keep them at par with their foreign counterparts.

Ayeni, \& Afolabi, (2012) examined the relationship between teachers' performance of instructional tasks and students' academic performance in the teaching-learning process of secondary schools. The study employed a descriptive survey design paradigm. Respondents consist of 60 principals, 540 teachers, and 1800 students that were randomly selected using the multi-stage sampling technique from a pool of 599 public secondary schools (now re-articulated into 301) in Ondo State, South-West, Nigeria. Research instruments tagged, “Teachers' Instructional Task Performance Rating Scale” (TITPRS), "Students' Rating Scale", Interview Guide for Principals, and Teachers' Focus Group Discussion Guide (FGD) were used for data collection. The hypothesis was tested for significance at $p<0.05$ probability level of significance, using the Pearson product-moment correlation statistics. The study reveals that the major instructional tasks performed by the teachers are the preparation of lesson notes, writing of a plan of work, and periodic assessment of students' learning. While the tasks that are least performed by teachers are research into teaching and learning activities, improvisation and usage of instructional materials, marking of exercises/ assignments, and regular feedback to students. Furthermore, the results show that the majority of students (62.2\%) perceived their teachers' performance of instructional tasks as very effective. Results 
also show that the relationship between teachers' instructional tasks and students' academic performance is significant $(r=0.828$ at $p<0.05)$ with the teachers' tasks (Mean $=42.17)$ and students' performance (Mean $=2.73$ ). This implies that many schools are still striving to achieve quality assurance in students' academic performance. The study concluded that improvement in the tasks of instructional resource inputs, curriculum delivery, and students' learning requires effective and goal-oriented interrelationship between the school and other stakeholders in education.

Joseph \& Philias (2011) looked at the class size as it relates to the academic performance of students in the Ekiti State of Nigeria between 1990 and 1997. The study population was the results of the West African School Certificate Examinations (WASCE) conducted between 1990 and 1997 in 50 secondary schools in both rural and urban areas of the state. One validated instrument Students' Class Size Questionnaire (SCSQ) was used for data collection. One hypothesis was formulated and answered. Data were analyzed using mean and t-test. The result showed that there was no significant difference in the academic achievement of students in small and large classes from urban schools $(t=1.49 ; p<0.05)$; there is no significant difference between the performance of students from rural large and rural small classes $(t=0.58 ; p<0.05)$. It was recommended that policymakers and the government should ensure that more classrooms are built and the number of students in a class should not be more than 30 . The Parent-Teacher Association (PTA), philanthropist, and other charitable organizations are also implored to compliment the effort of the government to boost the performance of students in SSCE by building more classrooms and buildings.

Ige (2013) Observed that secondary education is critical to the education of a child, being the bridge between primary and tertiary education. In his paper, he discussed the challenges militating against the achievement of the objectives of secondary education in Nigeria. They include inadequate funds; inadequate and decay infrastructural facilities; inadequate and low-quality teachers; negative attitudes of teachers; indiscipline of students; examination malpractices; low-quality students-intake and poor academic performance of students; wastage; inappropriate curriculum; as well as the dilemma of disarticulation of schools. To tackle these challenges, and move secondary education forward in this decade and beyond, the paper suggested the provision of adequate fund for secondary education; effective administration of secondary schools; curbing examination malpractices; recruitment and training of more teachers; commitment and effectiveness of teachers; re-articulation of disarticulated schools; regular and effective inspection of secondary schools; recruitment of quality candidates into secondary schools; and review of secondary education curriculum.

From the above-reviewed literature, it is obvious that there is a research gap in the planning aspect of Nigerian secondary school education. It is imperative to investigate the challenges facing the planning of secondary schools in FCT, Abuja, Nigeria.

The objectives of this study are to find out the challenges facing the planning of Secondary Schools education in FCT, Abuja, Nigeria. The other objectives are to:

1. To find out if inadequate data/information is a problem facing the planning of secondary schools in FCT.

2. To find out if inadequate planning materials are a problem facing the planning of secondary schools in FCT.

3. To find out if poor training is responsible for the problem of poor planning of secondary schools in FCT.

4. To find out if political instability is a problem facing the planning of secondary schools in FCT.

5. To find out if inadequate funding of planning activities is a problem facing the planning of secondary schools in FCT.

6. To find out if the shortage of professional educational planners a problem facing planning of secondary schools in FCT

The following research question where generated to guide this study:

1. Is inadequate data/information a problem facing the planning of secondary schools in FCT?

2. Is inadequate planning materials a problem facing the planning of secondary schools in FCT?

3. Is poor training for educational planners responsible for the problem of poor planning of secondary schools in FCT? 
4. Is political instability a problem facing the planning of secondary schools in FCT?

5. Is inadequate funding of planning activities a problem facing planning of secondary schools in FCT?

6. Is a shortage of professional educational planners a problem facing planning of secondary schools in FCT?

\section{METHOD}

The research design for the study was a survey method. The study was carried out in FCT Abuja, Nigeria. The target population is comprised of educational planners working in the ministry, department, and agency of education that deals with education planning. The sample for this study was eighty (80), by random sampling technique using four agencies of the federal government in FCT, Abuja. The structured questionnaire type was used as the major instrument for data collection. This was divided into two parts; $\mathrm{A}$ and B. Part A contained personal data of the respondents and part B consisted of the research questions and was divided into six subsections to obtain information on the various research questions posed by this investigation. A four-point rating scale was adopted and is shown as follows: Strongly Agree $(\mathrm{SA})=$ (4points) Agree $(A)=(3$ points $)$, Disagree $(D)=(2$ points $)$ and Strongly Disagree $(A D)=(1$ point $)$

The reliability of the instrument was determined through the test and re-test. The trial - test was done on some selected ten educational planners in Kogi state closer to FCT, Abuja. The trial was conducted twice on the same set of randomly selected educational planners in the ministry of education, with two - week gap between the test and the test. Pearson's product-moment method was used to obtain a reliability coefficient to indicate the reliability of the instrument. The questionnaire was sent to the respondents in their offices through a research assistant. The questions were completed on the spot and returned to the researcher immediately. The data were analyzed using frequency count and simple percentage.

\section{RESULTS AND DISCUSSION}

Research Question 1: Is inadequate data/information a problem facing planning of secondary schools education in FCT?

Table 1. Inadequate data/information is a problem facing planning of secondary schools education in FCT?

\begin{tabular}{|c|c|c|}
\hline Responses & Frequency & Percentage (\%) \\
\hline Strongly Agree & 54 & 67.5 \\
\hline Agree & 26 & 32.5 \\
\hline Disagree & 0 & 0.0 \\
\hline Strongly Disagree & 00 & 0.0 \\
\hline Total & 80 & 100 \\
\hline \multicolumn{2}{|c|}{ Source: Elaborated by author }
\end{tabular}

To find out if inadequate data/information is a problem facing the planning of secondary school education in FCT. Table one result revealed that $67.5 \%$ of the respondents chose strongly to agree and $32.5 \%$ also chose to agree that inadequate data/information is a problem facing planning of secondary schools education in FCT. This means that $100 \%$ of the respondents agreed that inadequate data/information is a problem facing the planning of secondary school education in FCT.

Research Question 2: Is inadequate planning materials a problem facing planning of secondary schools education in FCT? 
Table 2: Inadequate planning materials is a problem facing the planning of secondary school education in FCT.

\begin{tabular}{|c|c|c|}
\hline Responses & Frequency & Percentage (\%) \\
\hline Strongly Agree & 53 & 66.25 \\
\hline Agree & 27 & 33.75 \\
\hline Disagree & 0 & 0.0 \\
\hline Strongly Disagree & 00 & 0.0 \\
\hline Total & 80 & 100 \\
\hline \multicolumn{2}{|c|}{ Source: Elaborated by author. }
\end{tabular}

To find out if inadequate planning materials are a problem facing the planning of secondary schools education in FCT. Table two showed that $66.25 \%$ of the respondents ticked strongly agree while $33.75 \%$ ticked strongly disagree inadequate planning materials is a problem facing planning of secondary schools education in FCT. This implication of this result is that the public servant in charge of planning education in FCT agreed that inadequate planning materials are a problem facing the planning of secondary school education in FCT.

Research Question 3: Is poor training for educational planners responsible for the problem of poor planning of secondary schools education in FCT?

Table 3: Poor training for educational planners is responsible for the problem of poor planning of secondary schools education in FCT.

\begin{tabular}{|c|c|c|}
\hline Responses & Frequency & Percentage (\%) \\
\hline Strongly Agree & 39 & 48.75 \\
\hline Agree & 26 & 32.25 \\
\hline Disagree & 12 & 15 \\
\hline Strongly Disagree & 03 & 3.75 \\
\hline Total & 80 & 100 \\
\hline \multicolumn{2}{|c|}{ Source: Elaborated by author. } \\
\hline
\end{tabular}

To find out if poor training for educational planners is responsible for the problem of poor planning of secondary schools education in FCT. Table three result disclosed that $48.75 \%$ of the respondents ticked strongly agree, $32.5 \%$ of the respondent ticked agree while $15 \%$ of the respondents ticked strongly disagree and $3.75 \%$ ticked disagree. This means that the majority of the sampled respondent agreed that poor training for educational planners is responsible for the problem of poor planning of secondary schools education in FCT. education in FCT?

Research Question 4: Is political instability a problem facing planning of secondary schools

Table 4: If political instability a problem facing planning of secondary schools education in FCT.

\begin{tabular}{|c|c|c|}
\hline Responses & Frequency & Percentage (\%) \\
\hline Strongly Agree & 48 & 47.5 \\
\hline Agree & 22 & 27.5 \\
\hline Disagree & 11 & 13.75 \\
\hline Strongly Disagree & 9 & 11.25 \\
\hline Total & 80 & 100 \\
\hline \multicolumn{2}{|c|}{ Source: Elaborated by author. } \\
\hline
\end{tabular}

To find out if political instability is a problem facing the planning of secondary schools education in FCT. Results collected in table four revealed that $47.5 \%$ and $27.5 \%$ of the sampled respondents ticked strongly agree and agree respectively while $13.75 \%$ and $11.25 \%$ of the respondents also ticked strongly disagree and disagree that political instability is a problem facing planning of secondary schools education in FCT. This means that the majority of the educational planners in the ministry of education in Abuja agreed that political instability is a problem facing the planning of secondary schools education in FCT. 
Research Question 5: Is inadequate funding of planning activities a problem facing planning of secondary schools education in FCT?

Table 5: Inadequate funding of planning activities is a problem facing planning of secondary schools education in FCT.

\begin{tabular}{|c|c|c|}
\hline Responses & Frequency & Percentage (\%) \\
\hline Strongly Agree & 49 & 61.25 \\
\hline Agree & 31 & 38.75 \\
\hline Disagree & 0 & 0.0 \\
\hline Strongly Disagree & 00 & 0.0 \\
\hline Total & 80 & 100 \\
\hline
\end{tabular}

To find out if political instability is a problem facing the planning of secondary schools education in FCT. Table five indicated that $61.25 \%$ of the sampled respondents choose strongly agree while $38.25 \%$ also choose to agree that Inadequate funding of planning activities is a problem facing the planning of secondary schools education in FCT. This implies that $100 \%$ of the sampled respondents in charge of secondary school education planning believe agreed that inadequate funding of planning activities is a problem facing the planning of secondary school education in FCT.

Research Question 6: Is shortage of professional educational planners a problem facing planning of secondary schools education in FCT?

Table 6: Shortage of professional educational planners is a problem facing planning of secondary schools education in FCT.

\begin{tabular}{|c|c|c|}
\hline Responses & Frequency & Percentage (\%) \\
\hline Strongly Agree & 29 & 36.25 \\
\hline Agree & 51 & $63-75$ \\
\hline Disagree & 0 & 00.0 \\
\hline Strongly Disagree & 00 & 00.0 \\
\hline Total & 80 & 100 \\
\hline \multicolumn{2}{|c|}{ Source: Elaborated by author. }
\end{tabular}

To find out if a shortage of professional educational planners is a problem facing the planning of secondary schools education in FCT. Table six results showed that $36.25 \%$ of the respondents ticked strongly agree and $63.75 \%$ ticked agree that the shortage of professional educational planners is a problem facing the planning of secondary schools education in FCT. This means that educational planners in FCT sampled for in this study agreed that shortage of professional educational planners a problem facing planning of secondary schools education in FCT.

\section{CONCLUSION}

The objective of this study was to find out the challenges facing the planning of secondary schools education in FCT, Abuja, Nigeria and the other objectives are to:

1. To find out if inadequate data/information is a problem facing the planning of secondary schools in FCT.

2. To find out if inadequate planning materials are a problem facing the planning of secondary schools in FCT.

3. To find out if poor training of educational planner is responsible for the problem of poor planning of secondary schools in FCT. in FCT.

4. To find out if political instability is a problem facing the planning of secondary schools

5. To find out if inadequate funding of planning activities is a problem facing the planning of secondary schools in FCT. 
6. To find out if a shortage of professional educational planners a problem facing planning of secondary schools in FCT.

Result collected on each of the research question designed for the study showed that the sampled respondents which were made of educational planners working in the ministry and department of educational planners in FCT agreed that: inadequate data/information for planning, inadequate planning materials, poor training of educational planner, political instability, inadequate funding of planning activities and shortage of professional educational planners are the challenges facing the planning of secondary schools in FCT, Abuja, Nigeria.

\section{CONFLICT OF INTEREST}

No potential conflict of interest is reported by the author(s).

\section{FUNDING}

There is no financial assistance in studies from external parties.

\section{ACKNOWLEDGEMENTS}

N/A

\section{REFERENCES}

Ayeni, A., \& Afolabi, E. (2012). Teachers' instructional task performance and quality assurance of students' learning outcomes in Nigerian secondary schools. International Journal of Research Studies in Educational Technology, 1(1), 33-42. https:// www.learntechlib.org/p/49782/

Adepoju, T. L (2000). Planning for an effective Educational Policy in Nigeria. A planner's view. In, J. O. Fadipe and E. E. Oluchu $\mathrm{Kwu}(\mathrm{ed})$. Educational Planning and Administration in Nigeria in the 21st century. Ibandan, NIEPA

Akpan , C. P. (2000). Effective planning: A pre-requisite for successful implementation of the Universal Basic Education (UBE) scheme. International Journal of Research in Basic and Life-Long Education, 1(1), 103-109.

Edame, G. E. (2015). Planning as an instrument for national development in Nigeria. Global Journal of Management and Business Research in Economics and Commerce, 15(4), 15-20.

Joseph, S. O., \& Philias, O. Y. (2011). Class Size and Academic Achievement of Secondary School in Ekiti State, Nigeria. Asian Social Sciences, 7(6), 184-189. https://doi.org/10.5539/ass.v7n6p184

Ige, A. M. (2013) Provision of secondary education in Nigeria: Challenges and way forward. Journal of African Studies and Development, 5(1), 1-9, https://doi.org/10.5897/JASD11.058

Muhammad A. I., \& Bint M, Y. (2012).Teachers Challenges in Nigerian Public Secondary Schools Climate: Implications on Students Dropouts. Science Journal of Sociology and Anthropology, (2012), 1-7. https://www.sjpub.org/sjsa/abstract/sjsa125.html

Nnebedum, C., \& Akinfolarin, A. V. (2017). Principals' Supervisory Techniques as Correlates of Teachers' Job Performance in Secondary Schools in Ebonyi State, Nigeria. International Journal for Social Studies, 3(10), 13-22 https://journals.eduindex. org/index.php/ijss/article/view/6441

Nwachukwu, P. O. (2013). The Problems and Approaches to Educational Planning in Nigeria: A Theoretical Observation. Mediterranean Journal of Social Sciences, 4(12), 37-48. http://dx.doi.org/10.5901/mjss.2013.v4n12p37

National Open University of Nigeria. (2008). Legal aspects of educational administration. Lagos Office.

Peretomode, V. F. (1991). Educational Administration: Applied concept and Theoretical Perspective. Lagos: Joja Educational Research and Publishers.

Peretomode, V. F. (1995). Introduction to Educational Administration Planning and Supervision. Lagos: Joja Educational Research and Publishers.

Ogundele, A. (2004). Planning an Effective Educational Programme for Nigerian Schools. Ibadan: Tony Ben Publishers.

\section{AUTHOR}

Ogunod Niyi Jacob. Is a professional educational planner and had worked with different private Schools as a professional teacher and planning officer. Currently with Federal University Wukari as an academic planning officer. $\mathrm{He}$ is a researcher with publication in education, especially educational planning. He has a B.Sc (Ed) Economics [UNIABJ] and a master of educational administration and planning [NOUN]. 